\title{
Article \\ Shorter Survival after Liver Pedicle Clamping in Patients Undergoing Liver Resection for Hepatocellular Carcinoma Revealed by a Systematic Review and Meta-Analysis
}

\author{
Charles-Henri Wassmer *, Beat Moeckli * (D), Thierry Berney, Christian Toso and Lorenzo A. Orci
}

check for updates

Citation: Wassmer, C.-H.; Moeckli, B.; Berney, T.; Toso, C.; Orci, L.A. Shorter Survival after Liver Pedicle Clamping in Patients Undergoing Liver Resection for Hepatocellular Carcinoma Revealed by a Systematic Review and Meta-Analysis. Cancers 2021, 13, 637. https://doi.org/ 10.3390/cancers13040637

Academic Editors: Alessandro Vitale and Quirino Lai

Received: 26 January 2021

Accepted: 1 February 2021

Published: 5 February 2021

Publisher's Note: MDPI stays neutral with regard to jurisdictional claims in published maps and institutional affiliations.

Copyright: (c) 2021 by the authors. Licensee MDPI, Basel, Switzerland. This article is an open access article distributed under the terms and conditions of the Creative Commons Attribution (CC BY) license (https:// creativecommons.org/licenses/by/ $4.0 /)$.
Division of Abdominal and Transplantation Surgery, Department of Surgery, Faculty of Medicine, Geneva University Hospitals, 4 rue Gabrielle-Perret-Gentil, 1205 Geneva, Switzerland; thierry.berney@hcuge.ch (T.B.); christian.toso@hcuge.ch (C.T.); lorenzo.orci@hcuge.ch (L.A.O.)

* Correspondence: charles-henri.wassmer@hcuge.ch (C.-H.W.); beat.moeckli@etu.unige.ch (B.M.); Tel.: +41-7866-82206 (C.-H.W.)

Simple Summary: Hepatocellular carcinoma (HCC) is the most prevalent tumor of the liver and represents the second most common cause of oncological-related deaths worldwide. Despite all progress made in the field, surgical resection or liver transplantation are, at the moment, the only curative therapies available. Liver resection, especially for large, central tumors, are at risk of important bleeding. Significative hemorrhage during HCC resections have been linked to an increased rate of post-operative complications and tumor recurrence. Therefore, hepatic pedicle clamping during surgery has been used in order to reduce the bleeding risks. However, this method induces ischemia/reperfusion injuries, which has also been associated with tumor recurrence. For this reason, we aimed to evaluate if pedicle clamping is indeed associated with tumor recurrence and shorter survival, by performing a systematic review of the literature and meta-analysis.

Abstract: Liver pedicle clamping minimizes surgical bleeding during hepatectomy. However, by inducing ischemia-reperfusion injury to the remnant liver, pedicle clamping may be associated with tumor recurrence in the regenerating liver. Hepatocellular carcinoma (HCC) having a high rate of recurrence, evidences demonstrating an eventual association with pedicle clamping is strongly needed. We did a systematic review of the literature until April 2020, looking at studies reporting the impact of liver pedicle clamping on long-term outcomes in patients undergoing liver resection for HCC. Primary and secondary outcomes were overall survival (OS) and disease-free survival, respectively. Results were obtained by random-effect meta-analysis and expressed as standardized mean difference (SMD). Eleven studies were included, accounting for 8087 patients. Results of seven studies were pooled in a meta-analysis. Findings indicated that, as compared to control patients who did not receive liver pedicle clamping, those who did had a significantly shorter OS (SMD $=-0.172$, 95\%CI: -0.298 to $-0.047, p=0.007, I^{2}=76.8 \%$ ) and higher tumor recurrence rates (odds ratio 1.36 1.01 to 1.83. $p=0.044, I^{2}=50.7 \%$ ). This meta-analysis suggests that liver pedicle clamping may have a deleterious impact on long-term outcomes. An individual patient-data meta-analysis of randomized trials evaluating liver pedicle clamping is urgently needed.

Keywords: Pringle; hepatocellular carcinoma; liver resection; portal clamping; survival

\section{Introduction}

Hepatocellular carcinoma (HCC) is the most common primary malignancy of the liver. It is a leading cause for cancer-related death at the global stage, accounting for nearly 745,000 deaths per year [1,2]. Due to late diagnosis and limited therapeutic options, $\mathrm{HCC}$ has an elevated mortality rate, with an overall five-year survival rate below $20 \%$ [3]. Among several therapeutic approaches [4], hepatectomy and liver transplantation are the 
only curative options. Liver resection in particular, is indicated in patients with early-stage HCC and preserved liver function [5].

In patients with large tumors or those in anatomically difficult locations, liver resection may be a technically demanding procedure, with the potential of significant blood loss. Over the past decades, improvements in surgical and perioperative care have contributed to reduce peri-operative mortality after hepatectomy [6,7], which lies around 3\% in many cohorts [8,9]. With evidence supporting that parenchymal bleeding and blood transfusions associated with poor outcomes providing the impetus to achieve vascular control during liver resection [10-13], a classical approach for minimizing surgical blood loss is to interrupt liver blood inflow during parenchymal transection. Liver pedicle clamping, or the Pringle maneuver, was first described by James Hogarth Pringle in the beginning of the 20th century as a way to control hemorrhaging for patients with liver trauma [14]. Many surgeons still use pedicle clamping to control bleeding and reduce liver transection time [15-17]. With the development of laparoscopic liver resection, the Pringle maneuver has regained some popularity, given that hemostasis can be more difficult to achieve during laparoscopy than in open surgery [18].

Vascular inflow occlusion comes at the cost of inducing ischemia-reperfusion (IR) injury to the remnant liver parenchyma [19]. Depending on the duration of pedicle clamping and the severity of underlying parenchymal abnormalities [20-22], the release of radical oxygen species, microvascular changes and the induction of inflammatory pathways during reperfusion can lead to postoperative liver dysfunction, increased perioperative complications and prolonged recovery [23-25]. But beyond early peri-operative morbidity, our group, among others, has contributed in demonstrating that liver IR injury promotes the engraftment and proliferation of circulating tumor cells [26-29]. This is particularly relevant to the surgical context, where mobilization of the liver can lead to a release of tumor cells, which may encounter a favorable environment for engraftment and growth in the remnant ischemic, regenerative liver [30-33]. These observations are in line with evidence from the liver transplantation field, where it has been shown that prolonged liver warm ischemia is associated with increased tumor recurrence rates after liver transplantation for HCC [34-36]. Other known risk factors for negative adverse oncological outcomes after surgery include severe blood loss, prolonged operating time, positive surgical margin, and postoperative complications [13,37-39].

The impact of pedicle clamping on early post-operative morbidity has been studied in various randomized controlled trials [40-45]. Surprisingly, these studies did not report long-term outcomes. The current systematic review and meta-analysis aims at synthesizing the available evidence to evaluate whether liver inflow occlusion is associated with a shorter overall survival, or increased rates of tumor recurrence.

\section{Results}

\subsection{Characteristics of the Included Studies, Intervention Groups, and Critical Appraisal}

Ninety-two publications were identified and scrutinized for inclusion. After reviewing abstracts, 21 publications were considered potentially eligible. Finally, after full text assessment, 11 studies [46-56] were included (Figure 1). All studies but one [52] were of retrospective design. One study was considered prospective, as it was a secondary, long-term, nested analysis of the results of two randomized trials comparing intermittent pedicle clamping to no clamping [52]. In this secondary analysis, authors assessed tumor recurrence among other relevant oncological endpoints, years after the original publication. To our knowledge, this is the only long-term re-assessment of the many randomized trials evaluating the impact on liver pedicle clamping. 


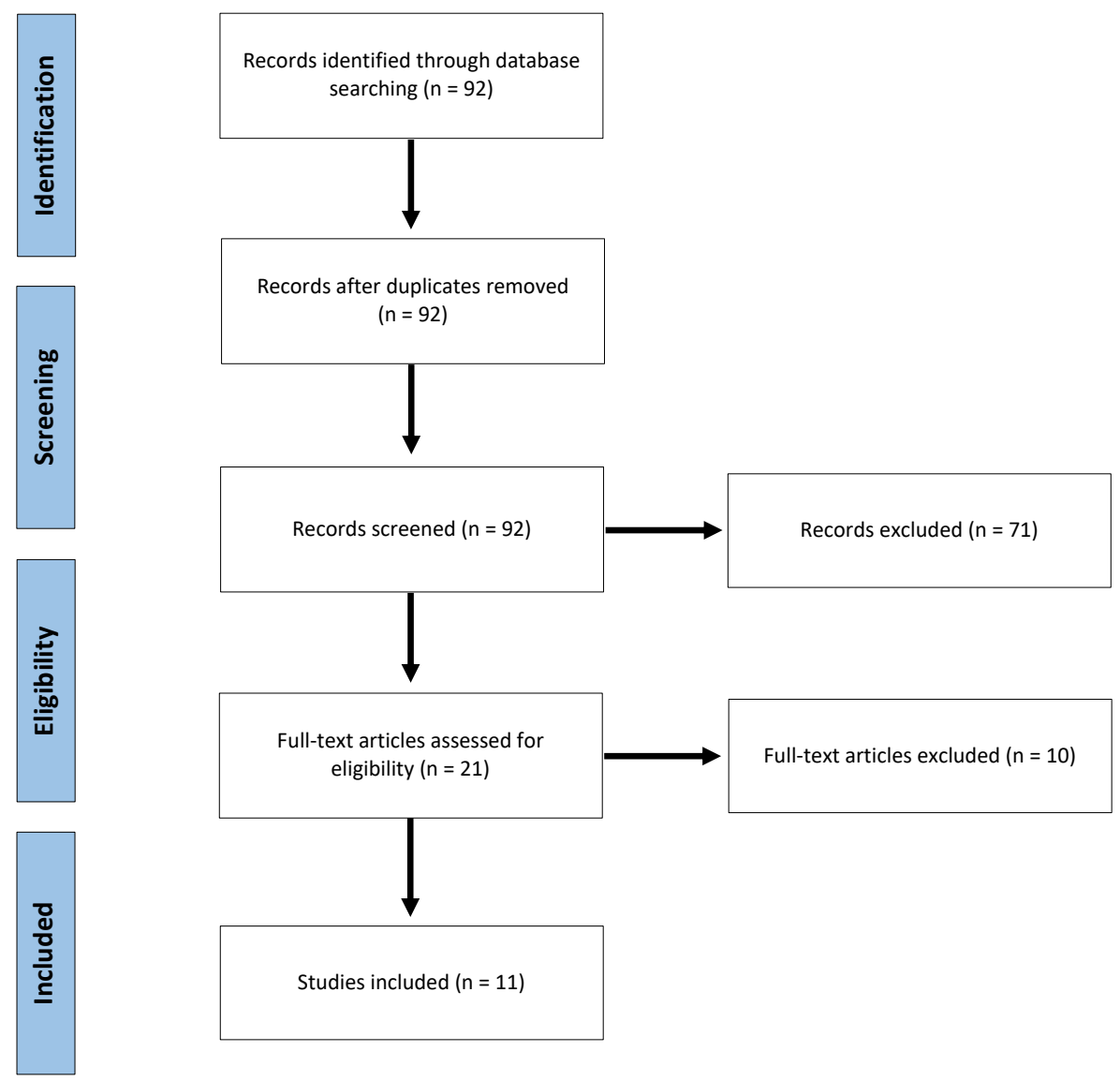

Figure 1. Flow Chart of the inclusion-exclusion process, according to the Preferred Reporting Items for Systematic Reviews and Meta-Analyses.

Eight studies originated from China, one from Hong-Kong, one from Japan and one from Italy (Table 1). Overall, the included studies reported data on 8281 patients. Note that Jiang et al. [47] built a propensity score to allow for baseline imbalance between groups, and through this score, only 202 out of the 396 original patients were matched. Therefore, the total number of patients retained in the current systematic review was 8087 .

Among all patients, 6505 (80.4\%) were male and 6421 (79.3\%) displayed liver cirrhosis. Regarding tumor characteristics, 1459 (18\%) had multinodular HCC and $1782(29.9 \%)$ patients underwent a major hepatectomy (Ishizuka et al. [51], Jiang et al. [47] and Li et al. [55] did not report this information in their study, and the last percentage was calculated out of 6127 cases). Regarding the surgical approach, seven studies specified that only cases of open liver resection were included. Famularo et al. [46], Jiang et al. [47], Li et al. [55], and Liu et al. [54], did not provide further details on the surgical technique.

Pedicle clamping was applied in 4674 (57.8\%) patients, either continuous or intermittent. There was marked variability in terms of the type and duration of clamping. Nine studies used intermittent clamping [46-50,52,54-56]. The two other studies used continuous inflow occlusion $[51,53]$ and stratified their study population in groups undergoing increasing duration of clamping. Characteristics of the included studies are summarized in Tables 1 and 2. 
Table 1. Study characteristics.

\begin{tabular}{|c|c|c|c|c|c|c|c|c|}
\hline Study & Year & Country & Design (Period) & $\begin{array}{l}\text { Primary } \\
\text { Outcome }\end{array}$ & $\begin{array}{l}\text { Secondary } \\
\text { Outcome }\end{array}$ & $\begin{array}{l}\text { Total No. of } \\
\text { Patients }\end{array}$ & $\begin{array}{c}\text { Age, Year } \\
\text { (Range/SD) }\end{array}$ & $\begin{array}{l}\text { Follow Up } \\
\text { (Months) }\end{array}$ \\
\hline Famularo et al. [46] & 2018 & Italy & RCS (2001-2015) & OS & DFS & 441 & $67(58.7-73.0)^{\mathrm{a}}$ & 60 \\
\hline Hao et al. [49] & 2016 & China & RCS (2010-2012) & OS & DFS & 266 & $48,5 \pm 10.3^{b}$ & 25 \\
\hline Hao et al. [48] & 2017 & China & RCS (2007-2010) & OS & DFS & 355 & $48,5 \pm 10.3^{b}$ & $49.7(6-66)^{\mathrm{a}}$ \\
\hline Huang et al. [50] & 2014 & China & RCS (1998-2008) & OS & DFS & 1549 & 56,1 & $68.4 \pm 57.8^{b}$ \\
\hline Ishizuka et al. [51] & 2011 & Japan & RCS (2000-2008) & OS & DFS & 357 & $67(28-85)^{\mathrm{a}}$ & $32.7 \pm 23.6^{b}$ \\
\hline Jiang et al. [47] & 2017 & China & RCS (2004-2009) & OS & DFS & 202 & 47 & 60.7 \\
\hline Lee et al. [52] & 2019 & Hong Kong & $\begin{array}{l}\text { nested-analysis of two } \\
\text { randomized trials } \\
(2008-2011,2013-2016)\end{array}$ & OS & DFS & 176 & $59.3(27-84)$ & $44.3(0.2-120.2)^{\mathrm{a}}$ \\
\hline Li et al. [55] & 2016 & China & RCS (2003-2006) & OS & DFS & 1401 & NR & 120 \\
\hline Liu et al. [54] & 2016 & China & RCS (1999-2008) & OS & DFS & 2368 & NR & 52.2 \\
\hline Xia et al. [56] & 2013 & China & RCS (2001-2006) & OS & DFS & 386 & 53 & 120 \\
\hline Xu et al. [53] & 2017 & China & RCS (1989-2011) & OS & DFS & 586 & 56,1 & $36(1-157)^{a}$ \\
\hline
\end{tabular}

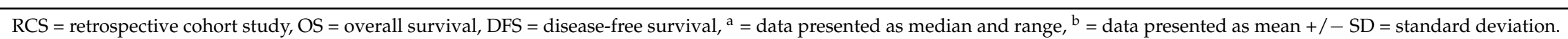


Table 2. Patient, tumor and treatment characteristics according to clamping groups.

\begin{tabular}{|c|c|c|c|c|c|c|c|c|c|c|c|c|c|c|c|c|c|}
\hline & & & & & & & & & & & & & & & ear OS & & ear DFS \\
\hline Study & Group & $\begin{array}{c}\text { No. of } \\
\text { Patients }\end{array}$ & Age, Year & $\begin{array}{l}\text { Male, } \\
\text { n (\%) }\end{array}$ & $\begin{array}{c}\text { Cirrhosis, } \\
\text { n (\%) }\end{array}$ & $\begin{array}{l}\text { Clamping } \\
\text { Interval } \\
\text { (min) }\end{array}$ & $\begin{array}{c}\text { Total } \\
\text { Clamping } \\
\text { Time, min }\end{array}$ & $\underset{(\mathrm{ng} / \mathrm{mL})}{\mathrm{AFP}}$ & $\begin{array}{c}\text { Multiple } \\
\text { Lesions, } \\
\text { n (\%) }\end{array}$ & $\begin{array}{c}\text { Tumor } \\
\text { Size, cm }\end{array}$ & $\begin{array}{c}\text { Surgery } \\
\text { Duration, } \\
\text { min }\end{array}$ & $\begin{array}{c}\text { Major } \\
\text { Resection, } \\
\text { n (\%) }\end{array}$ & $\begin{array}{c}\text { Blood } \\
\text { Loss, mL }\end{array}$ & $\begin{array}{l}\text { Rate } \\
(\%)\end{array}$ & $\begin{array}{l}\text { Median, } \\
\text { Months }\end{array}$ & $\begin{array}{l}\text { Rate } \\
(\%)\end{array}$ & $\begin{array}{l}\text { Median, } \\
\text { Months }\end{array}$ \\
\hline \multirow[t]{4}{*}{$\begin{array}{l}\text { Famularo et al. } \\
2018 \text { [46] }\end{array}$} & $\begin{array}{l}\mathrm{IPC} \leq \\
15 \mathrm{~min}\end{array}$ & 176 & $\begin{array}{c}65.1 \\
(58)-72)^{a}\end{array}$ & $\begin{array}{l}145 \\
(824)\end{array}$ & $144(82.3)$ & $15 ; 5$ & $23(14-30)^{\mathrm{a}}$ & $\begin{array}{c}25.4 \\
(73-1597)^{b}\end{array}$ & $42(24)$ & $56(31.8)^{\mathrm{e}}$ & $\begin{array}{c}170 \\
(140-270) \text { a }\end{array}$ & $22(12.5)$ & $\begin{array}{c}400 \\
(50-700) \text { a }\end{array}$ & / & $\begin{array}{c}60.6(24.9- \\
96.8) \\
\mathrm{g}\end{array}$ & / & $\begin{array}{c}26.7(15.7- \\
37.7)\end{array}$ \\
\hline & $\begin{array}{c}16- \\
30 \mathrm{~min}\end{array}$ & & & & & & & & & & & & & & $\begin{array}{c}44.0(33.0- \\
54.9) \\
\mathrm{g}\end{array}$ & & g \\
\hline & $>30 \mathrm{~min}$ & & & & & & & & & & & & & & $\begin{array}{c}30.3(23.9- \\
36.8) \\
\mathrm{g}\end{array}$ & & \\
\hline & NPC & 265 & $\begin{array}{c}67.6 \\
(59.2-73.9)^{a}\end{array}$ & $\begin{array}{c}199 \\
(75.1)\end{array}$ & $214(80.8)$ & NA & NA & $\begin{array}{c}21.8 \\
(7.3-214.2)^{b}\end{array}$ & 54 (20.5) & $65(24.5)^{\mathrm{e}}$ & $70 \underset{\mathrm{a}}{(125-210)}$ & $36(12.2)$ & $\begin{array}{c}300 \\
(50-600)^{\text {a }}\end{array}$ & / & $\begin{array}{c}56.5(37.1- \\
75.9) \\
\mathrm{g}\end{array}$ & / & $\begin{array}{c}24.9(18.1- \\
31.7) \\
\mathrm{g}\end{array}$ \\
\hline \multirow[t]{3}{*}{$\begin{array}{l}\text { Hao et al. } \\
2016 \text { [49] }\end{array}$} & IPC & 78 & $51.7^{\mathrm{b}}$ & $\begin{array}{c}60 \\
(77.9)\end{array}$ & $78(100)$ & $15 ; 5$ & $31.5 \underset{\mathrm{b}}{ \pm} 12.5$ & / & 31 (39.7) & $46(59.0)^{\mathrm{f}}$ & $187 \pm 31^{\mathrm{b}}$ & $50(64.1)$ & $\underset{\mathrm{b}}{396 \pm 78}$ & $72.7^{8}$ & $\underset{\mathrm{b}, \mathrm{h}}{19 \pm 4.2}$ & $\begin{array}{c}63.6 \\
\mathrm{~h}\end{array}$ & $\underset{\mathrm{b}, \mathrm{h}}{14.2 \pm} 4.6$ \\
\hline & СPC & 128 & $53.6^{\mathrm{b}}$ & $\begin{array}{c}101 \\
(78.9)\end{array}$ & $128(100)$ & NA & $27.7 \pm 7.3^{b}$ & / & 45 (35.2) & $70(54.7)^{\mathrm{f}}$ & $132 \pm 26^{\mathrm{b}}$ & $77(60.2)$ & $\underset{\mathrm{b}}{422 \pm 75}$ & 79.98 & $\underset{\mathrm{b}, \mathrm{h}}{20 \pm 3.8}$ & $\underset{\mathrm{h}}{75.8}$ & $\underset{\mathrm{b}, \mathrm{h}}{18 \pm 4.8}$ \\
\hline & NPC & 60 & $55.0^{\mathrm{b}}$ & $\begin{array}{c}48 \\
(80.0)\end{array}$ & $60(100)$ & NA & NA & / & $21(35.0)$ & $34(56.7)^{f}$ & $140 \pm 22^{b}$ & $15(25.0)$ & $\underset{\mathrm{b}}{405 \pm 83}$ & $83.1^{g}$ & $\underset{\mathrm{b}, \mathrm{h}}{22.5} \pm .1$ & $78^{\mathrm{h}}$ & $\underset{\mathrm{b}, \mathrm{h}}{19.0} \pm 4.1$ \\
\hline \multirow[t]{2}{*}{$\begin{array}{l}\text { Hao et al. } \\
2017 \text { [48] }\end{array}$} & IPC & 113 & $51.7^{\mathrm{b}}$ & $\begin{array}{c}76 \\
(67.3)\end{array}$ & $113(100)$ & $15 ; 5$ & / & / & $46(40.7)$ & $73(35.4)^{f}$ & / & $71(62.8)$ & I & 44.9 & 46.3 & 42.5 & 39.4 \\
\hline & OPC & 190 & $53.6^{\mathrm{b}}$ & $\begin{array}{c}130 \\
(68.4)\end{array}$ & $190(100)$ & NA & / & / & 73 (38.4) & $114(40)^{\mathrm{f}}$ & / & $110(57.9)$ & / & 58 & 52.9 & 50.9 & 47.3 \\
\hline \multirow[t]{3}{*}{$\begin{array}{l}\text { Huang et al. } \\
2014 \text { [50] }\end{array}$} & IPC & 712 & $56.1 \frac{ \pm}{\mathrm{b}} 16.5$ & $\begin{array}{l}505 \\
(70.9)\end{array}$ & $518(72.8)$ & $15 ; 5$ & $47.4 \underset{\mathrm{b}}{ \pm} 38.7$ & $\begin{array}{l}8176.3^{ \pm} \\
3211.5^{\mathrm{b}}\end{array}$ & 199 (27.9) & $8.6 \frac{ \pm}{\mathrm{b}} 7.8$ & $172.1 \underset{\mathrm{b}}{ \pm} 95.9$ & 338 (47.5) & $\begin{array}{c}1146.3^{ \pm} \\
895.2^{\mathrm{b}}\end{array}$ & \multirow[t]{2}{*}{42} & / & \multirow[t]{2}{*}{22} & / \\
\hline & SPC & 219 & $57.2 \underset{\mathrm{b}}{ \pm} 19.4$ & $\begin{array}{c}162 \\
(74.0)\end{array}$ & $164(74.9)$ & $30 ; 5$ & $53.1 \underset{\mathrm{b}}{ \pm} 33.5$ & $\begin{array}{l}6776.3 \pm \\
2771.8^{\mathrm{b}}\end{array}$ & 64 (29.2) & $6.3 \pm 4.4$ & $\begin{array}{l}200.4^{ \pm} \\
119.4^{\mathrm{b}}\end{array}$ & $78(35.6)$ & $\begin{array}{c}1311.8 \pm \\
785.4^{\mathrm{b}}\end{array}$ & & / & & / \\
\hline & NPC & 618 & $54.2 \underset{\mathrm{b}}{ \pm} 22.1$ & $\begin{array}{c}473 \\
(76.5)\end{array}$ & $322(52.1)$ & NA & NA & $\begin{array}{l}6421.2 \pm \\
5641.9^{\mathrm{b}}\end{array}$ & 185 (29.9) & $7.7 \underset{\mathrm{b}}{ \pm} 5.1$ & $\begin{array}{l}248.8 \pm \\
146.1^{\mathrm{b}}\end{array}$ & $289(46.8)$ & $\begin{array}{l}1428.6 \pm t \\
1123.7^{\mathrm{b}}\end{array}$ & 35 & / & \multirow[t]{2}{*}{18} & / \\
\hline $\begin{array}{l}\text { Ishizuka et al. } \\
2011 \text { [51] }\end{array}$ & $\begin{array}{l}\mathrm{PC} \leq \\
60 \mathrm{~min}\end{array}$ & 242 & $68(28-85)^{\mathrm{a}}$ & $\begin{array}{l}194 \\
(80.2)\end{array}$ & $126(52.1)$ & $15 ; 5$ & $53.7 \underset{\mathrm{b}}{ \pm} 26.1$ & $\begin{array}{c}24(3-779 \\
000)^{\mathrm{a}}\end{array}$ & $54(22.3)$ & $\begin{array}{c}2.5 \\
(0.5-25)^{a}\end{array}$ & $\begin{array}{c}280 \\
(123-683)^{a}\end{array}$ & / & $\begin{array}{c}437 \\
\underset{\mathrm{a}}{(60-6840)} \\
\mathrm{a}\end{array}$ & & $\begin{array}{l}32.1 \pm \\
23.7^{\mathrm{b}}\end{array}$ & & / \\
\hline
\end{tabular}


Table 2. Cont.

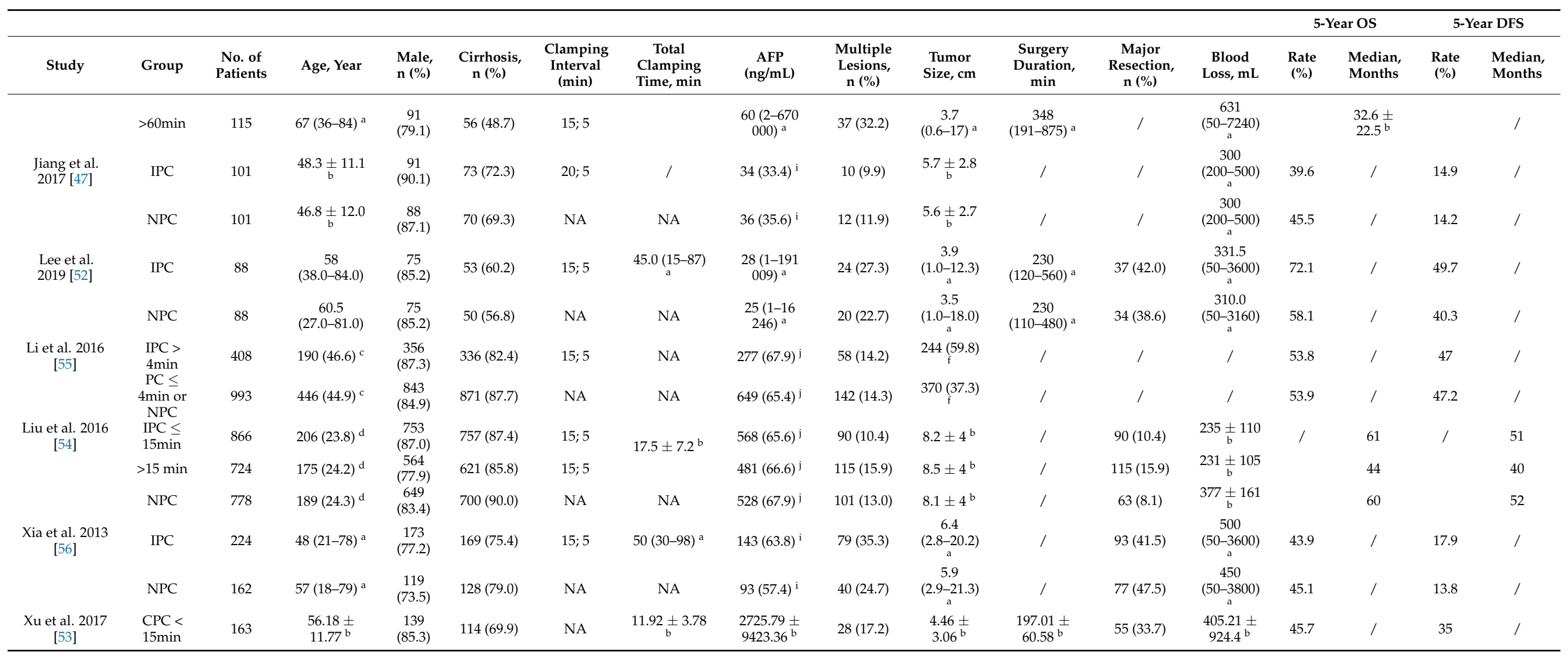


Table 2. Cont.

\begin{tabular}{|c|c|c|c|c|c|c|c|c|c|c|c|c|c|c|c|c|c|}
\hline \multirow[b]{2}{*}{ Study } & \multirow[b]{2}{*}{ Group } & \multirow[b]{2}{*}{$\begin{array}{l}\text { No. of } \\
\text { Patients }\end{array}$} & \multirow[b]{2}{*}{ Age, Year } & \multirow[b]{2}{*}{$\begin{array}{l}\text { Male, } \\
\text { n (\%) }\end{array}$} & \multirow[b]{2}{*}{$\begin{array}{l}\text { Cirrhosis, } \\
\text { n (\%) }\end{array}$} & \multirow[b]{2}{*}{$\begin{array}{l}\text { Clamping } \\
\text { Interval } \\
\text { (min) }\end{array}$} & \multirow[b]{2}{*}{$\begin{array}{c}\text { Total } \\
\text { Clamping } \\
\text { Time, min }\end{array}$} & \multirow[b]{2}{*}{$\underset{(\mathrm{ng} / \mathrm{mL})}{\mathrm{AFP}}$} & \multirow[b]{2}{*}{$\begin{array}{c}\text { Multiple } \\
\text { Lesions, } \\
\text { n (\%) }\end{array}$} & \multirow[b]{2}{*}{$\begin{array}{l}\text { Tumor } \\
\text { Size, cm }\end{array}$} & \multirow[b]{2}{*}{$\begin{array}{c}\text { Surgery } \\
\text { Duration, } \\
\text { min }\end{array}$} & \multirow[b]{2}{*}{$\begin{array}{c}\text { Major } \\
\text { Resection, } \\
\text { n (\%) }\end{array}$} & \multirow[b]{2}{*}{$\begin{array}{c}\text { Blood } \\
\text { Loss, mL }\end{array}$} & \multicolumn{2}{|c|}{ 5-Year OS } & \multicolumn{2}{|c|}{ 5-Year DFS } \\
\hline & & & & & & & & & & & & & & $\begin{array}{l}\text { Rate } \\
(\%)\end{array}$ & $\begin{array}{l}\text { Median, } \\
\text { Months }\end{array}$ & $\begin{array}{l}\text { Rate } \\
(\%)\end{array}$ & $\begin{array}{l}\text { Median, } \\
\text { Months }\end{array}$ \\
\hline & $\geq 15 \mathrm{~min}$ & 127 & $\begin{array}{l}55.87 \pm \\
11.15^{\mathrm{b}}\end{array}$ & $\begin{array}{c}113 \\
(89.0)\end{array}$ & 93 (73.2) & NA & $25.05 \pm 3.3 .60$ & $\begin{array}{c}8736.39 \pm \\
39,952.35^{\mathrm{b}}\end{array}$ & $24(18.9)$ & $\begin{array}{l}6.28 \pm \\
3.26^{\mathrm{b}}\end{array}$ & $\begin{array}{c}227.40 \pm \\
55.14^{\mathrm{b}}\end{array}$ & $50(39.4)$ & $\begin{array}{c}618.50 \pm \\
606.2^{\mathrm{b}}\end{array}$ & 42.5 & / & 33.2 & / \\
\hline & NPC & 296 & $\begin{array}{l}56.10 \pm \\
12.05^{\mathrm{b}}\end{array}$ & $\begin{array}{c}246 \\
(83.1)\end{array}$ & $221(74.7)$ & NA & NA & $\begin{array}{c}4526.09 \pm \\
15,714.95^{\mathrm{b}}\end{array}$ & 47 (15.9) & $\begin{array}{l}5.76 \pm \\
4.12^{\mathrm{b}}\end{array}$ & $\begin{array}{c}215.69 \pm \\
88.58^{\mathrm{b}}\end{array}$ & $126(42.6)$ & $\begin{array}{l}783.55 \pm \\
1554.4^{\mathrm{b}}\end{array}$ & 39.7 & / & 33.9 & / \\
\hline
\end{tabular}

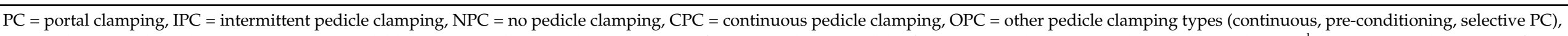

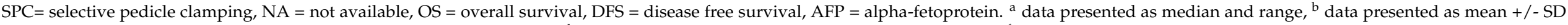

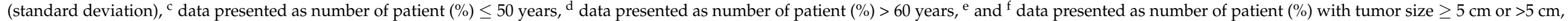

respectively, ${ }^{\mathrm{g}}$ data presented as median $(95 \% \mathrm{CI}),{ }^{\mathrm{h}}$ results at 1 year, ${ }^{\mathrm{i}}$ data presented as number of patient $(\%)$ with AFP $\geq 400 \mathrm{ng} / \mathrm{mL},{ }^{\mathrm{j}}$ data presented as number of patient $(\%)$ with $\mathrm{AFP} \geq 20 \mathrm{ng} / \mathrm{mL}$. 
We designed a network plot to facilitate the review of the study groups and comparisons evaluated in the current systematic review (Figure 2). The most common comparison was between "intermittent pedicle clamping" and "no clamping".

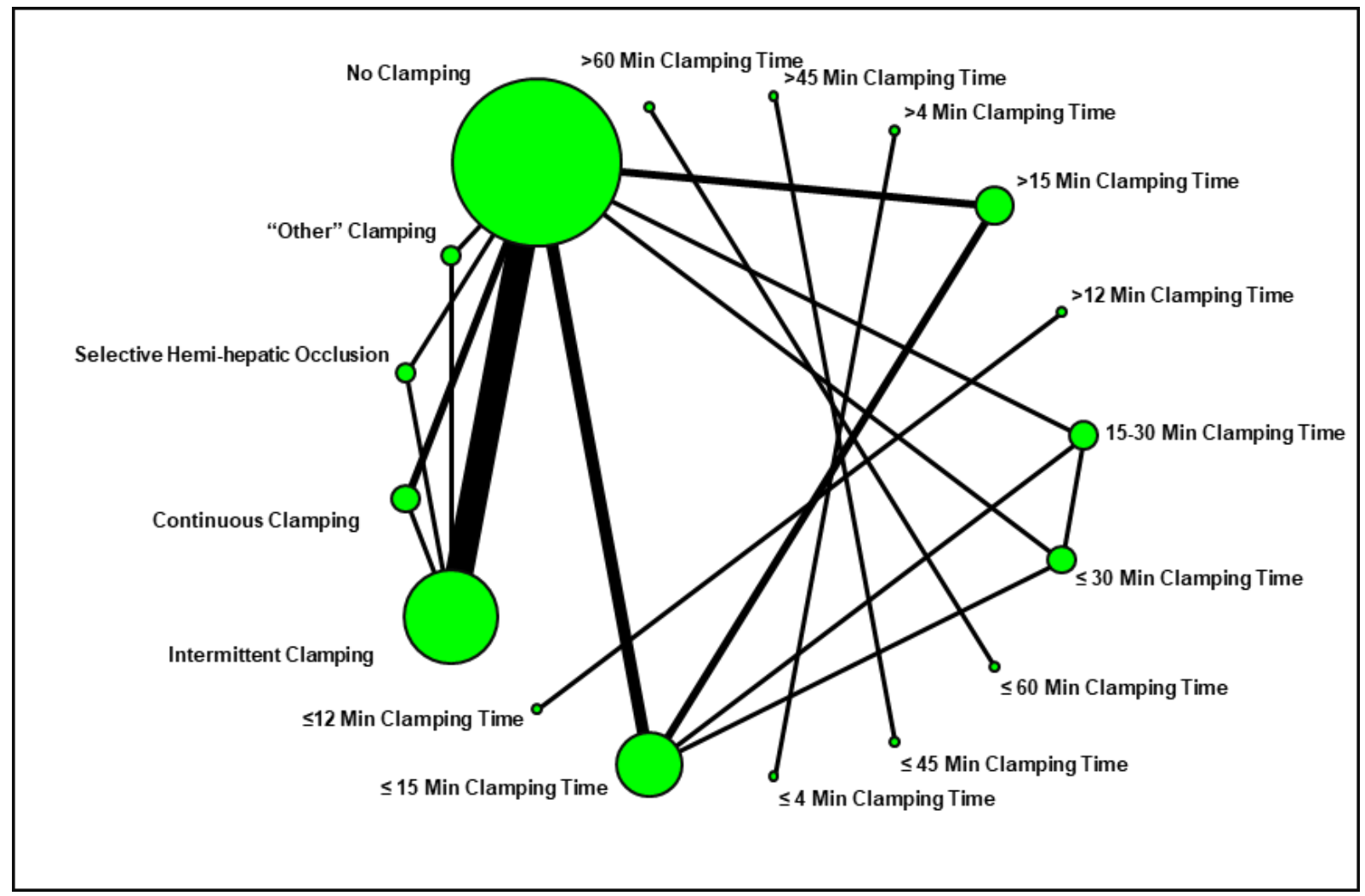

Figure 2. Network plot summarizing the comparisons assessed in the current systematic review.

When comparing, by meta-analysis, the baseline characteristics of the study groups (Table S1), we found no evidence to support a difference in terms of gender $(p=0.961)$, presence of underlying liver cirrhosis $(p=0.139)$, blood level of alpha-fetoprotein $(p=0.558)$, tumor size $(p=0.673)$, or in the proportion of patients with multinodular HCC $(p=0.812)$. However, a finer qualitative appraisal by the investigators revealed that some studies did in fact carry some baseline imbalance, especially in terms of tumor size and adequacy of the follow-up (Figure 3). On the basis of the Newcastle-Ottawa quality rating assessment, eight out of 11 studies [46-48,52-56] were considered of high quality (NOS $\geq 6$ ).

\subsection{Meta-Analysis of the Impact of Pedicle Clamping on Patient Survival and Tumor Recurrence}

Data from seven studies were used in the quantitative synthesis [46,48,49,52-54,56]. These studies provided a comparison of one (or more) pedicle clamping group(s) vs. a negative control group that did not undergo any clamping. Other studies could not be pooled, mostly due to the lack of an adequate control intervention [55]. We did not retain the study by Huang et al. [50] for meta-analysis because it compared pedicle clamping with a selective hemi-hepatic inflow occlusion technique, and no other comparator was reported. Similarly, Ishizuka et al. [51] could not be used because there was no control group without pedicle clamping. The study by Jiang et al. [47] was not included, because the occlusion group included patients with both total and partial pedicle clamping, making this group ill-defined. Note that three studies $[46,53,54]$ provided multiple clamping durations and were therefore entered in the analysis as distinct comparisons. 


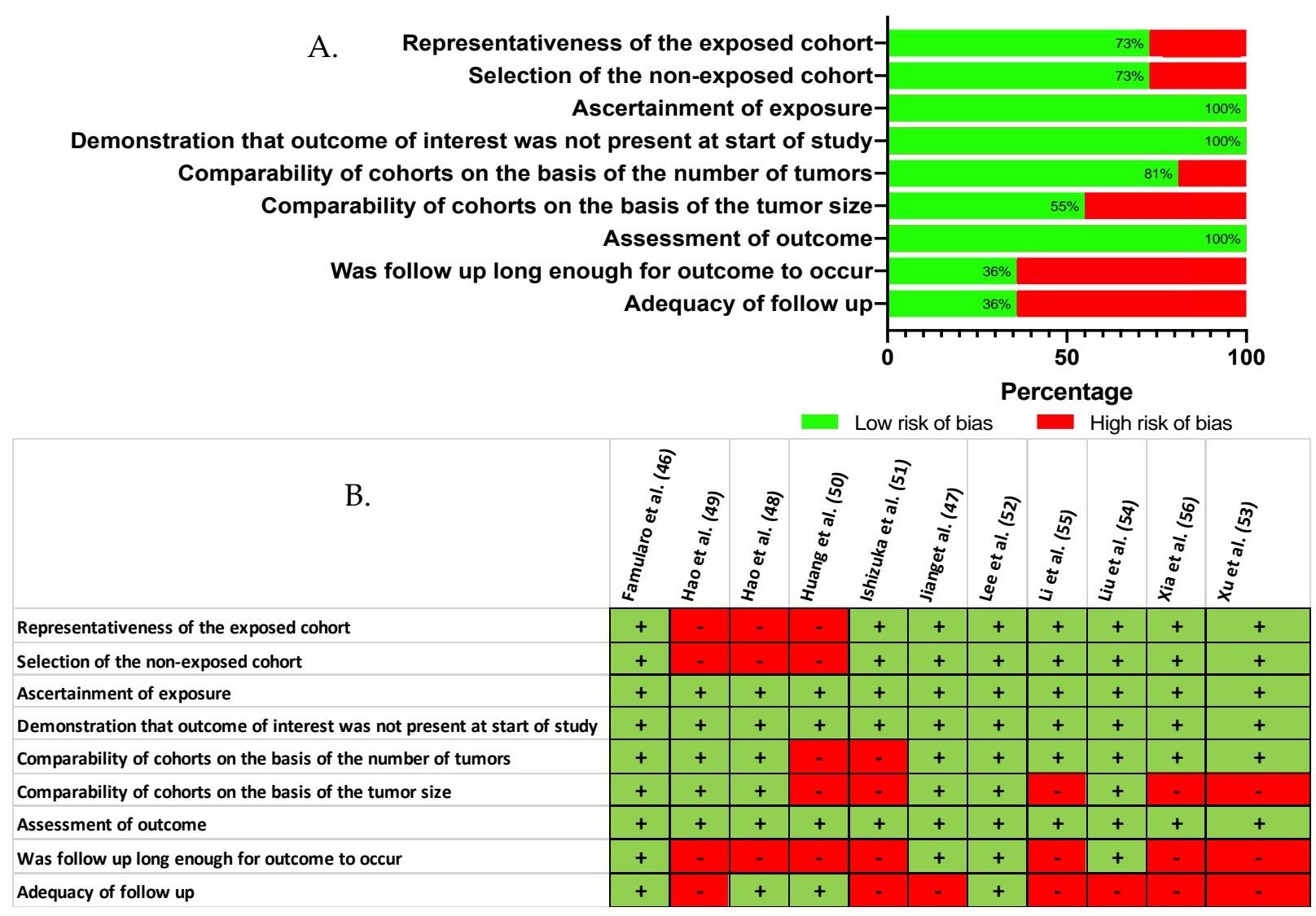

Figure 3. Critical appraisal of the reviewed literature, according to the Newcastle Ottawa Scale (A) Reviewer's judgment about the risk of bias item presented as percentages across all included studies (NOS) (B) Risk of bias as estimated by the authors for each item and each study that was included [46-56].

For the primary outcome of interest, meta-analysis indicated that patients who underwent pedicle clamping had a significantly shorter pooled overall survival, as compared to those without clamping (standardized mean difference $=-0.17$ (95\%CI: -0.298 to -0.047 ), $p=0.007, I^{2}=76.8 \%$, Figure $\left.4 \mathrm{~A}\right)$. This indicates a small effect size and corresponds to a 4.8 months shorter overall survival ( $95 \% \mathrm{CI}$ : -7.6 to -2.0 , weighted mean difference). We observed a trend of similar magnitude when looking at disease-free survival, but results were not statistically significant (standardized mean difference $=-0.11(95 \% \mathrm{CI}-0.27$ to $+0.048), p=0.174, I^{2}=85.7 \%$; Figure $4 \mathrm{~B}$ ). Of note, while we could not incorporate the results of Lee et al. [52] in this analysis on the primary outcome (due to insufficient data to extract median survival), one may object that the results would have shifted the meta-analysis towards the null. Indeed, in this study (55), the no clamping group had a significantly longer survival than the clamping group.

We next assessed whether pedicle clamping was associated with tumor recurrence. To this end, we compared, by random effects meta-analysis, the observed probability of recurrence throughout the assessed literature (Figure 4C). Consistent with our findings on the primary outcome, we found some evidence to support that, as compared to patients who had undergone clamping-free liver resection, those who received pedicle clamping were at risk of tumor relapse (pooled odds ratio 1.361 .01 to 1.83. $p=0.044, I^{2}=50.7 \%$ ). 


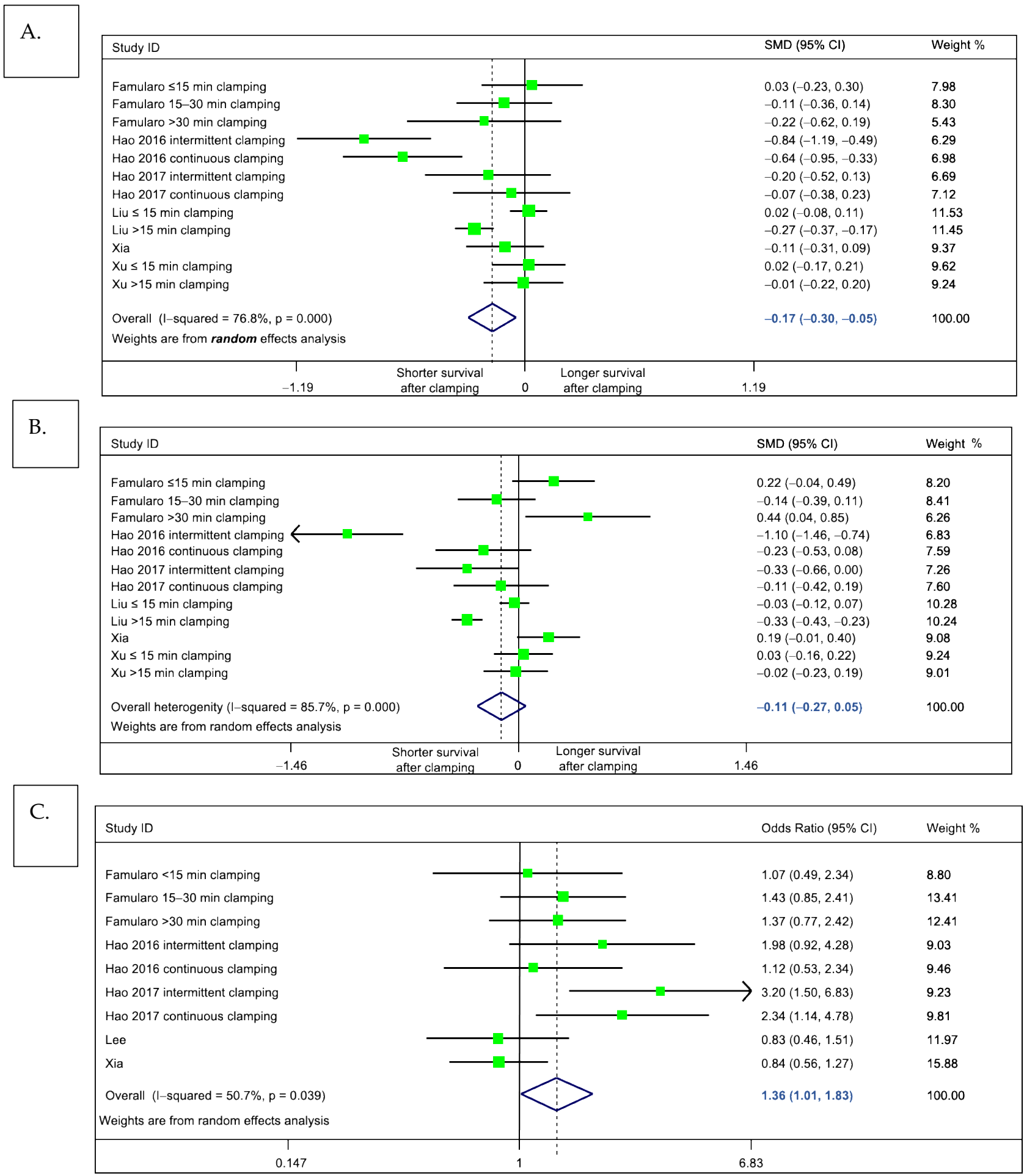

Figure 4. Meta-analysis comparing outcomes of patients undergoing liver pedicle clamping, versus no-clamping. Forest plots depict results obtained by random-effects meta-analysis. The vertical solid line depicts the null hypothesis, and the dashed line indicates the pooled effect estimate. (A) Primary outcome, overall survival (standardized mean difference). (B) Secondary outcome, disease-free survival (standardized mean difference). (C) Secondary outcome, overall probability of tumor recurrence (odds ratio). Note that in the main meta-analyses, the study by Huang et al. was excluded, because it included a subgroup of patients with unclear pedicle clamping technique ("other clamping"). In a sensitivity analysis including this study, the pooled effect estimate did not differ from the main analysis. 


\subsection{Investigation of Heterogeneity with Sensitivity Analyses and Meta-Regression}

Because high heterogeneity was observed in our meta-analysis $\left(I^{2}>75 \%\right)$, we did several sensitivity analyses (Table 3) to explore potential sources of heterogeneity. In particular, we looked at the impact of the following factors: (i) duration of pedicle clamping (pooling only studies with prolonged clamping time), (ii) methodological quality of the studies (pooling only studies at low-risk of bias, or NOS $\geq 6$ ), (iii) relevance of the imputation techniques that we used for missing data (by running all meta-analyses once again, but this time assuming a worst-case scenario where missing values were filled with the highest observed variance) and (iv) by including the study by Huang et al. [50] despite the unclear nature of the subgroup entitled "other pedicle clamping".

Table 3. Results of the sensitivity analyses.

\begin{tabular}{|c|c|c|c|c|}
\hline Factor Assessed & $\begin{array}{c}\text { Number of } \\
\text { Comparisons }\end{array}$ & $\begin{array}{l}\text { Pooled Estimate } \\
(95 \% \text { CI })\end{array}$ & $p$-Value & Heterogeneity \\
\hline $\begin{array}{l}\text { Prolonged (>15 min) } \\
\text { clamping time }\end{array}$ & 4 & $\begin{array}{c}\mathrm{SMD}=-0.220(-0.304 \\
\text { to }-0.137)\end{array}$ & $<0.001$ & $\mathrm{Q}$ test $p=0.436, \mathrm{I}^{2}=0 \%$ \\
\hline $\begin{array}{l}\text { Standard deviation } \\
\text { assumption using a } \\
\text { worst-case scenario }\end{array}$ & 11 & $\begin{array}{c}\mathrm{SMD}=-0.150(-0.272 \\
\text { to }-0.028)\end{array}$ & 0.016 & $\mathrm{Q}$ test $p<0.1, \mathrm{I}^{2}=73 \%$ \\
\hline $\begin{array}{c}\text { Pooling only } \\
\text { high-quality studies } \\
\text { only }(\text { NOS } \geq 6)\end{array}$ & 8 & $\begin{array}{c}\mathrm{SMD}=-0.110(-0.223 \\
\text { to }-0.002)\end{array}$ & 0.055 & $\mathrm{Q}$ test $p<0.1, \mathrm{I}^{2}=60 \%$ \\
\hline $\begin{array}{l}\text { Inclusion of the study } \\
\text { by Huang et al. [50] }\end{array}$ & 12 & $\begin{array}{c}\mathrm{SMD}=-0.157(-0.294 \\
\text { to }-0.019)\end{array}$ & 0.026 & $\mathrm{Q}$ test $p<0.1, \mathrm{I}^{2}=84 \%$ \\
\hline
\end{tabular}

$\mathrm{SMD}=$ Standardized Median Difference.

Interestingly, clamping time had the largest impact on the statistical heterogeneity. By restricting the analysis to studies (or subgroups of patients) with prolonged clamping time, we could suppress heterogeneity (standardized mean difference $=-0.22(95 \% \mathrm{CI}$ -0.30 to -0.14$), p=<0.001 I^{2}=0 \%$, Q Test $p=0.436$; Figure 5). Other factors did not have a marked impact on statistical heterogeneity (Table 3).

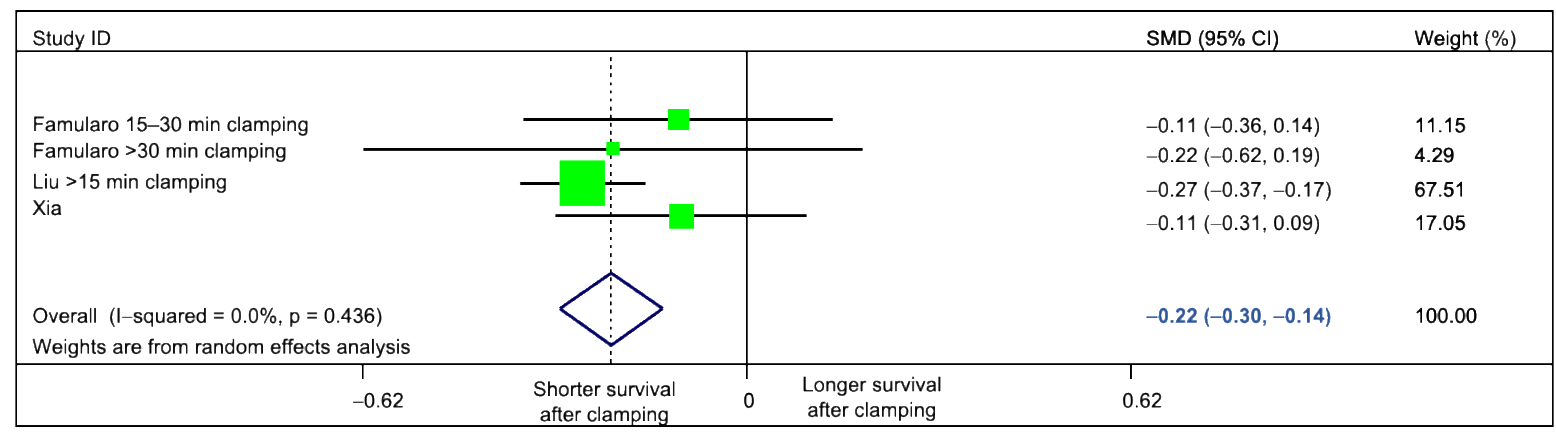

Figure 5. Sensitivity analysis, evaluating the impact of clamping time on the measured statistical heterogeneity. Only studies comparing prolonged ( $\geq 15 \mathrm{~min}$ ) clamping time versus no-clamping were pooled. Residual heterogeneity was $0 \%$.

We further evaluated whether methodological quality of the included studies may have affected the results. To this end, we did a meta-regression analysis plotting the methodological quality against the main effect estimate, and found that studies of increasingly robust design tended to identify an increasingly deleterious impact of pedicle clamping on overall survival (Figure 6). 


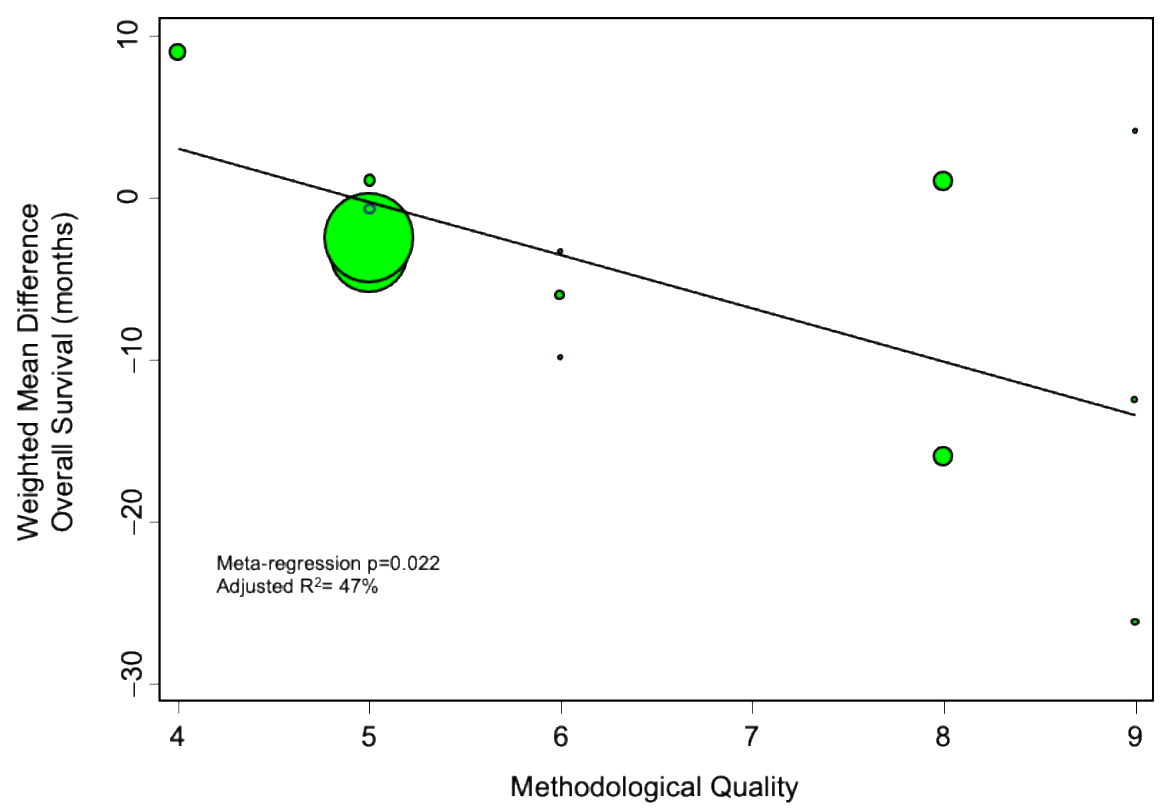

Figure 6. Meta-regression analysis, evaluating the impact of methodological quality (as assessed by the Newcastle-Ottawa scale) on the calculated pooled estimate. The more negative the weighted mean difference, the more harmful the effect of pedicle clamping on overall survival. The diameter of the individual studies indicates their relative weight in the meta-analysis.

\section{Discussion}

The current systematic review and meta-analysis, which aggregates data on over 8000 patients with resectable HCC, evaluated the impact of hepatic pedicle clamping during liver resection on long-term oncological outcomes. We found that portal vascular clamping was associated with a shorter overall survival and higher tumor recurrence rates. This potentially harmful effect of pedicle clamping was more pronounced in patients undergoing longer clamping times ( $>15 \mathrm{~min})$. Remarkably, sensitivity analysis where only studies with prolonged clamping times were included, allowed to suppress the heterogeneity observed in the meta-analysis, confirming that clamping time is indeed an important factor affecting survival. A similar trend was identified in terms of disease-free survival, but results did not reach statistical significance.

A recent systematic review was published on a similar subject [57], reducing the originality of the current work. In their meta-analysis, Lin et al. included six studies that only compared intermittent portal clamping to no clamping [41,46,48-50,56]. Five of them were pooled quantitatively. Using this approach, authors did not identify a significant difference in terms of either overall or disease-free survival, albeit at the one-year timepoint. Lin et al. [57] concluded that the deleterious effect of inflow occlusion was relevant mostly on short-term outcomes. The main difference with our meta-analysis is that we also included studies comparing continuous liver pedicle clamping to no clamping, hypothesizing that both of these maneuvers provoke. Our analysis also went one step further and also looked at the impact of clamping time.

In 2013, Matsuda et al. looked at the impact of hepatic pedicle clamping on outcome of liver resection for colorectal liver metastasis [58]. Authors did not find significant difference terms of overall or disease-free survival, or intrahepatic recurrence between patients that underwent liver pedicle clamping and those who did not. Such discrepant results may be, at least in part, due to the markedly lower sample size in the review by Matsuda et al. ( $n=2114$ patients), and to the marked differences that exist in the mechanisms and patterns of tumor recurrence between HCC and colorectal liver metastasis.

Hepatic pedicle clamping is still widely used around the world. Results of a 2013 worldwide survey reported that liver pedicle clamping was used routinely in $50 \%$ of the surveyed hospitals [16]. In Japan, it is estimated that pedicle clamping is performed 
routinely in $25 \%$ of segmentectomies, in $9 \%$ of lobectomies, and in $34 \%$ depending on the indication [59]. A recent American national database analysis reported that American surgeons perform pedicle clamping in more than $25 \%$ of cases [60]. In Europe, this maneuver is used routinely by $20 \%$ of surgeons, and by $71 \%$ of them depending on the surgical indication [61]. Importantly, evidence gathered from randomized controlled trials points out that, when performed by expert hands, liver resection can be safely performed without pedicle clamping $[41,43]$. Similarly, there as to whether pedicle clamping significantly decreases blood loss or reduces operating time $[40,42,62]$.

Our meta-analysis is the first to show that portal triad clamping may have a harmful effect on long-term oncological outcomes. On the basis of this result, and in light of the absence of a clear benefit on short term outcomes, we consider that the use of vascular inflow occlusion during liver resection should be used for selected cases, or as a rescue option, and not as the rule in when planning routine hepatectomy. Selected cases may include redo hepatectomy, large or deeply located tumors [13], and complex laparoscopic cases. With these exceptions in mind, the number of patients requiring pedicle clamping should be limited, by focusing other important components of modern liver surgery, such as maintaining low central venous pressure, choosing the appropriate dissection plane, and cautiously ligating middle-size vessels and biliary canaliculi during parenchymal transection.

Nine of the included studies were published by Chinese research groups (one study was from Japan, and one from Italy), meaning that the results presented in the current meta-analysis may hardly be generalizable to non-Asian populations. Furthermore, there are other limitations to our work. First, with the exception of the study of Lee et al. [52], only retrospective studies were included, putting by definition our results at risk of several types of bias. The main putative bias in the current setting is bias by clinical indication, whereby surgeons may have been inclined to perform pedicle clamping in face of a given surgical situation (nature of the hepatectomy, location and size of the tumor, occurrence of major bleeding), rather than as a planned maneuver. Second, there was significant heterogeneity in our meta-analysis, and this calls for a cautious interpretation of the pooledeffect estimates reported herein. In this regard, we consider that the clinical variability in the included studies may have markedly contributed to statistical heterogeneity, as exemplified by the abrogation of heterogeneity when we pooled studies with similar clamping times. Note that long inclusion periods in some of the studies assessed herein [50,53,54] may also have had an adverse impact on statistical heterogeneity (due to practice changes in the clinical management of older vs. newer cases). Third, to enhance the number of group comparisons, we subdivided five of the included studies [46,48,49,53,54] into subgroups, and analyzed them as separate studies. Finally, while we opted for standardized and validated data imputation techniques for missing standard deviations, this may have affected the accuracy of our effect estimates. Note that the trends identified in the current meta-analysis remained robust even when applying a worst-case scenario with very large standard deviation.

Our results demonstrate that hepatic blood flow occlusion, during liver surgery for HCC resection, seems to negatively impact patient survival. This is in line with other pieces of evidence showing that an injured liver parenchyma portends an elevated risk of tumor recurrence [34-36]. More evidence from prospective studies is necessary on this topic and an ideal way to fill this gap would be to perform an individual patient metaanalysis, collecting the long-term outcomes from the numerous randomized controlled trials available on this subject, but focused on peri-operative outcomes.

\section{Methods}

\subsection{Literature Search, Study Selection, and Outcomes of Interest}

The protocol for this systematic review was registered in the Prospero database (CRD42018102641). We formulated a structured keyword search in Medline/PubMed, from January 1960 until 6 April 2020, in order to identify studies evaluating the impact of 
liver pedicle clamping on long-term outcomes after liver resection for HCC. The query was as follows:

[(portal) and (clamping)] OR [(inflow) and (occlusion)] OR [(hepatic) and (inflow)] OR [(liver [MeSH Terms) and (clamping)] OR [(pedicle) and (clamping)] OR [(pringle) and (maneuver)]

$A N D$

[(hepatocellular carcinoma [MeSH Terms]) and (recurrence)] OR [(survival)] OR [(long-term)] OR [(prognosis)]

Studies had either to provide at least a comparison between a liver pedicle-clamping group to a no clamping group in a head-to-head fashion. Studies comparing distinct forms of pedicle clamping were also retained. We only included studies that reported an estimation of patient overall survival beyond a 12-months period post-liver resection. Given that numerous randomized trials evaluated the impact of pedicle clamping on early post-operative morbidity [40-45], we particularly looked for secondary, long-term analyses of these studies. We excluded patients undergoing liver resection for colorectal liver metastases (or other indication than HCC) and case-series with less than ten patients. For the purpose of this review, we only assessed studies written in English.

\subsection{Data Extraction}

Two independents investigators (CH.W. and B.M.) scrutinized the database search, evaluated potential articles for inclusion, assessed study quality, and extracted data according to a pre-established review form (available upon request). Discrepancy was resolved by reaching a consensus with the senior reviewer (L.A.O.). We extracted the following data from the individual studies: author name, date of publication, country where the study took place, epidemiological design, the period during which the study took place, the total number of patients included and their characteristics (gender, age, presence of cirrhosis, number and size of the tumor nodules). We retrieved information on the technical aspect of the pedicle clamping method (continuous vs. intermittent, tourniquet vs. direct clamp application), the duration of liver inflow occlusion, operative time, blood loss, and the extension of liver resection (major resection being considered when $\geq 3$ segments were resected). Next, we retrieved long-term outcomes, collecting informations on all of the following endpoints: overall survival (primary outcome of interest), disease-free survival, point estimates of survival probability (1,3,5-years mean survival time), rate of tumor recurrence and duration of follow up.

\subsection{Risk of Bias Assessment}

Investigators assessed the risk of bias using the Newcastle-Ottawa scale (NOS). Briefly, each of the included study was evaluated on (i) the selection of the patients in each group (four items), (ii) the comparability between study groups (two items) and (iii) the method to assess outcomes (three items) [63]. Studies may be rated from 0 to 9 , with 9 indicating very low risk of bias. Of note, the number of tumor nodules and size of the largest tumor were chosen as factors to evaluate the comparability of the study groups.

\subsection{Quantitative Synthesis and Statistical Analysis}

We anticipated that a variety of pedicle clamping techniques would be reported throughout the literature. Therefore, we classified the distinct comparisons made in the individual studies by constructing a network plot, as described by Chaimani et al. [64]. In such a plot, the size of each dot represents the number of study arms, and the thickness of each connecting line represents the number of comparisons made between the given groups (e.g., whole pedicle clamping vs. no clamping, intermittent clamping vs. continuous clamping, prolonged vs. short continuous clamping). Whenever data were sufficient, outcomes were pooled and compared by random effects meta-analysis [65]. The primary comparison of interest to this meta-analysis looked at (a) patients undergoing portal triad clamping (either intermittent or continuous) versus (b) those undergoing no clamping at all. In this main analysis, studies reporting more than one comparison of clamping type or 
duration were considered as separate studies [66]. The aggregated effect size was expressed as a standardized mean difference in survival.

Between-study heterogeneity was calculated using the $I^{2}$ statistic, and was explored using several approaches. First, sensitivity analyses were performed to address the putative sources of heterogeneity. As another approach, we conducted meta-regression analyses to test for an association between bibliometric and clinical characteristics of the individual studies and their respective effect estimates. Factors assessed by meta-regression included study quality, the impact factor of the journal where studies were published, the extent of the liver resection, the number of tumor nodules, the size of the largest tumor, the median age of the cohort.

In case of missing summary statistics (such as mean values and standard deviations), we estimated them from medians and percentiles as proposed elsewhere [66,67]. Moreover, when necessary, relevant data were obtained by digitalizing results from the original figures, via high magnification and point estimation with the software GetData Graph Digitizer [68]. Statistical analyses were done using Stata software (v.15, College Station, TX, USA).

\section{Conclusions}

In conclusion, the current systematic review and meta-analysis suggests that prolonged liver pedicle clamping may be associated with shorter survival after liver resection for hepatocellular carcinoma. The risks and benefits of liver pedicle clamping need to be carefully weighed for each patient, taking into account local anatomy and aiming to optimize surgery and anesthesia in order to achieve minimal blood loss during parenchymotomy.

Supplementary Materials: The following are available online at https:/ / www.mdpi.com/2072-669 4/13/4/637/s1, Table S1: Meta-analysis comparing baseline characteristics of the study groups.

Author Contributions: Conception and design L.A.O., C.-H.W. Collection and assembly of data: C.-H.W., B.M. Data analysis and interpretation: L.A.O., C.-H.W. Manuscript writing: C.-H.W., B.M., L.A.O., C.T., T.B. All authors have read and agreed to the published version of the manuscript.

Funding: The authors received no financial support for the research, authorship, and/or publication of this article.

Institutional Review Board Statement: Not applicable.

Informed Consent Statement: Not applicable.

Data Availability Statement: The data presented in this study are available in this article (and supplementary material).

Conflicts of Interest: The authors declare that they have no conflict of interest.

\section{References}

1. World Health Organization. Global Cancer Observatory. Available online: https://gco.iarc.fr/today/home (accessed on 14 July 2020).

2. Ghouri, Y.A.; Mian, I.; Rowe, J.H. Review of hepatocellular carcinoma: Epidemiology, etiology, and carcinogenesis. J. Carcinog. 2017, 16, 1 .

3. Villanueva, A. Hepatocellular carcinoma. N. Engl. J. Med. 2019, 380, 1450-1462. [CrossRef] [PubMed]

4. Llovet, J.M.; Brú, C.; Bruix, J. Prognosis of hepatocellular carcinoma: The BCLC staging classification. Semin. Liver Dis. 1999, 19, 329-338. [CrossRef]

5. Bruix, J.; Takayama, T.; Mazzaferro, V.; Chau, G.-Y.; Yang, J.; Kudo, M.; Cai, J.; Poon, R.T.; Han, K.-H.; Tak, W.Y.; et al. Adjuvant sorafenib for hepatocellular carcinoma after resection or ablation (STORM): A phase 3, randomised, double-blind, placebocontrolled trial. Lancet Oncol. 2015, 16, 1344-1354. [CrossRef]

6. Lehmann, K.; Clavien, P.A. History of hepatic surgery. Surg. Clin. N. Am. 2010, 90, 655-664. [CrossRef]

7. Kaneko, H.; Otsuka, Y.; Kubota, Y.; Wakabayashi, G. Evolution and revolution of laparoscopic liver resection in Japan. Ann. Gastroenterol. Surg. 2017, 1, 33-43. [CrossRef] [PubMed]

8. Dokmak, S.; Fteriche, F.S.; Borscheid, R.; Cauchy, F.; Farges, O.; Belghiti, J. 2012 Liver resections in the 21st century: We are far from zero mortality. HPB 2013, 15, 908-915. [CrossRef]

9. Hoffmann, K.; Hinz, U.; Stravodimos, C.; Knoblich, T.; Schon, M.R.; Buchler, M.W.; Mehrabi, A. Risk assessment for liver resection. Surgery 2018, 164, 998-1005. [CrossRef] 
10. Wada, H.; Eguchi, H.; Nagano, H.; Kubo, S.; Nakai, T.; Kaibori, M.; Hayashi, M.; Takemura, S.; Tanaka, S.; Nakata, Y.; et al. Perioperative allogenic blood transfusion is a poor prognostic factor after hepatocellular carcinoma surgery: A multi-center analysis. Surg. Today 2018, 48, 73-79. [CrossRef]

11. Latchana, N.; Hirpara, D.H.; Hallet, J.; Karanicolas, P.J. Red blood cell transfusion in liver resection. Langenbecks Arch. Surg. 2019, 404, 1-9. [CrossRef]

12. Ibrahim, S.; Chen, C.L.; Lin, C.C.; Yang, C.H.; Wang, C.C.; Wang, S.H.; Liu, Y.W.; Yong, C.C.; Concejero, A.; Jawan, B.; et al. Intraoperative blood loss is a risk factor for complications in donors after living donor hepatectomy. Liver Transplant. 2006, $12,950-957$. [CrossRef] [PubMed]

13. Katz, S.C.; Shia, J.; Liau, K.H.; Gonen, M.; Ruo, L.; Jarnagin, W.R.; Fong, Y.; D'Angelica, M.I.; Blumgart, L.H.; Dematteo, R.P. Operative blood loss independently predicts recurrence and survival after resection of hepatocellular carcinoma. Ann. Surg. 2009, 249, 617-623. [CrossRef] [PubMed]

14. Pringle, J.H.V. Notes on the arrest of hepatic hemorrhage due to trauma. Ann. Surg. 1908, 48, 541-549. [CrossRef]

15. Hester, C.A.; El Mokdad, A.; Mansour, J.C.; Porembka, M.R.; Yopp, A.C.; Zeh, H.J., 3rd; Polanco, P.M. Current pattern of use and impact of pringle maneuver in liver resections in the United States. J. Surg. Res. 2019, 239, 253-260. [CrossRef] [PubMed]

16. Mise, Y.; Sakamoto, Y.; Ishizawa, T.; Kaneko, J.; Aoki, T.; Hasegawa, K.; Sugawara, Y.; Kokudo, N. A worldwide survey of the current daily practice in liver surgery. Liver Cancer 2013, 2, 55-66. [CrossRef]

17. Gurusamy, K.S.; Kumar, Y.; Ramamoorthy, R.; Sharma, D.; Davidson, B.R. Vascular occlusion for elective liver resections. Cochrane Database Syst. Rev. 2009, 21, CD007530. [CrossRef]

18. Kawaguchi, Y.; Nomi, T.; Fuks, D.; Mal, F.; Kokudo, N.; Gayet, B. Hemorrhage control for laparoscopic hepatectomy: Technical details and predictive factors for intraoperative blood loss. Surg. Endosc. 2016, 30, 2543-2551. [CrossRef]

19. Peralta, C.; Jimenez-Castro, M.B.; Gracia-Sancho, J. Hepatic ischemia and reperfusion injury: Effects on the liver sinusoidal milieu. J. Hepatol. 2013, 59, 1094-1106. [CrossRef]

20. Xue, H.; Guo, H.; Li, Y.C.; Hao, Z.M. Heme oxygenase-1 induction by hemin protects liver cells from ischemia/reperfusion injury in cirrhotic rats. World J. Gastroenterol. 2007, 13, 5384-5390. [CrossRef]

21. de Graaf, E.L.; Kench, J.; Dilworth, P.; Shackel, N.A.; Strasser, S.I.; Joseph, D.; Pleass, H.; Crawford, M.; McCaughan, G.W.; Verran, D.J. Grade of deceased donor liver macrovesicular steatosis impacts graft and recipient outcomes more than the donor risk index. J. Gastroenterol. Hepatol. 2012, 27, 540-546. [CrossRef]

22. Liss, K.H.H.; McCommis, K.S.; Chambers, K.T.; Pietka, T.A.; Schweitzer, G.G.; Park, S.L.; Nalbantoglu, I.; Weinheimer, C.J.; Hall, A.M.; Finck, B.N. The impact of diet-induced hepatic steatosis in a murine model of hepatic ischemia/reperfusion injury. Liver Transplant. 2018, 24, 908-921. [CrossRef] [PubMed]

23. Cannistra, M.; Ruggiero, M.; Zullo, A.; Gallelli, G.; Serafini, S.; Maria, M.; Naso, A.; Grande, R.; Serra, R.; Nardo, B. Hepatic ischemia reperfusion injury: A systematic review of literature and the role of current drugs and biomarkers. Int. J. Surg. 2016, 33 (Suppl. 1), S57-S70. [CrossRef] [PubMed]

24. de Graaf, W.; Heger, M.; Spruijt, O.; Maas, A.; de Bruin, K.; Hoekstra, R.; Bennink, R.J.; van Gulik, T.M. Quantitative assessment of liver function after ischemia-reperfusion injury and partial hepatectomy in rats. J. Surg. Res. 2012, 172, 85-94. [CrossRef]

25. Hammond, J.S.; Guha, I.N.; Beckingham, I.J.; Lobo, D.N. Prediction, prevention and management of postresection liver failure. Br. J. Surg. 2011, 98, 1188-1200. [CrossRef]

26. Orci, L.A.; Lacotte, S.; Delaune, V.; Slits, F.; Oldani, G.; Lazarevic, V.; Rossetti, C.; Rubbia-Brandt, L.; Morel, P.; Toso, C. Effects of the gut-liver axis on ischaemia-mediated hepatocellular carcinoma recurrence in the mouse liver. J. Hepatol. 2018, 68, 978-985. [CrossRef] [PubMed]

27. Orci, L.A.; Lacotte, S.; Oldani, G.; Morel, P.; Mentha, G.; Toso, C. The role of hepatic ischemia-reperfusion injury and liver parenchymal quality on cancer recurrence. Dig. Dis. Sci. 2014, 59, 2058-2068. [CrossRef]

28. Orci, L.A.; Lacotte, S.; Oldani, G.; Slits, F.; De Vito, C.; Crowe, L.A.; Rubbia-Brandt, L.; Vallee, J.P.; Morel, P.; Toso, C. Effect of ischaemic preconditioning on recurrence of hepatocellular carcinoma in an experimental model of liver steatosis. Br. J. Surg. 2016, 103, 417-426. [CrossRef] [PubMed]

29. Orci, L.A.; Toso, C.; Mentha, G.; Morel, P.; Majno, P.E. Systematic review and meta-analysis of the effect of perioperative steroids on ischaemia-reperfusion injury and surgical stress response in patients undergoing liver resection. Br. J. Surg. 2013, 100, 600-609. [CrossRef]

30. Kamo, N.; Ke, B.; Ghaffari, A.A.; Shen, X.D.; Busuttil, R.W.; Cheng, G.; Kupiec-Weglinski, J.W. ASC/Caspase-1/IL-1beta signaling triggers inflammatory responses by promoting HMGB1 induction in liver ischemia/reperfusion injury. Hepatology 2013, 58, 351-362. [CrossRef] [PubMed]

31. Uotani, H.; Yamashita, I.; Nagata, T.; Kishimoto, H.; Kashii, Y.; Tsukada, K. Induction of E-selectin after partial hepatectomy promotes metastases to liver in mice. J. Surg. Res. 2001, 96, 197-203. [CrossRef] [PubMed]

32. Harris, A.L. Hypoxia-A key regulatory factor in tumour growth. Nat. Rev. Cancer 2002, 2, 38-47. [CrossRef]

33. Toso, C.; Mentha, G.; Majno, P. Liver transplantation for hepatocellular carcinoma: Five steps to prevent recurrence. Am. J. Transplant. 2011, 11, 2031-2035. [CrossRef] [PubMed]

34. Li, C.X.; Man, K.; Lo, C.M. The impact of liver graft injury on cancer recurrence posttransplantation. Transplantation 2017, 101, 2665-2670. [CrossRef] 
35. Grat, M.; Krawczyk, M.; Wronka, K.M.; Stypulkowski, J.; Lewandowski, Z.; Wasilewicz, M.; Krawczyk, P.; Grat, K.; Patkowski, W.; Zieniewicz, K. Ischemia-Reperfusion injury and the risk of hepatocellular carcinoma recurrence after deceased donor liver transplantation. Sci. Rep. 2018, 8, 8935. [CrossRef] [PubMed]

36. Nagai, S.; Yoshida, A.; Facciuto, M.; Moonka, D.; Abouljoud, M.S.; Schwartz, M.E.; Florman, S.S. Ischemia time impacts recurrence of hepatocellular carcinoma after liver transplantation. Hepatology 2015, 61, 895-904. [CrossRef]

37. Tabrizian, P.; Jibara, G.; Shrager, B.; Schwartz, M.; Roayaie, S. Recurrence of hepatocellular cancer after resection: Patterns, treatments, and prognosis. Ann. Surg. 2015, 261, 947-955. [CrossRef]

38. Chok, K.S.; Ng, K.K.; Poon, R.T.; Lo, C.M.; Fan, S.T. Impact of postoperative complications on long-term outcome of curative resection for hepatocellular carcinoma. Br J Surg 2009, 96, 81-87. [CrossRef]

39. Park, J.H.; Koh, K.C.; Choi, M.S.; Lee, J.H.; Yoo, B.C.; Paik, S.W.; Rhee, J.C.; Joh, J.W. Analysis of risk factors associated with early multinodular recurrences after hepatic resection for hepatocellular carcinoma. Am. J. Surg. 2006, 192, 29-33. [CrossRef]

40. Maurer, C.A.; Walensi, M.; Kaser, S.A.; Kunzli, B.M.; Lotscher, R.; Zuse, A. Liver resections can be performed safely without Pringle maneuver: A prospective study. World J. Hepatol. 2016, 8, 1038-1046. [CrossRef]

41. Lee, K.F.; Wong, J.; Cheung, S.Y.S.; Chong, C.C.N.; Hui, J.W.Y.; Leung, V.Y.F.; Yu, S.C.H.; Lai, P.B.S. Does intermittent Pringle maneuver increase postoperative complications after hepatectomy for hepatocellular carcinoma? A randomized controlled trial. World J. Surg. 2018, 42, 3302-3311. [CrossRef] [PubMed]

42. Lee, K.F.; Cheung, Y.S.; Wong, J.; Chong, C.C.; Wong, J.S.; Lai, P.B. Randomized clinical trial of open hepatectomy with or without intermittent Pringle manoeuvre. Br. J. Surg. 2012, 99, 1203-1209. [CrossRef]

43. Capussotti, L.; Muratore, A.; Ferrero, A.; Massucco, P.; Ribero, D.; Polastri, R. Randomized clinical trial of liver resection with and without hepatic pedicle clamping. Br. J. Surg. 2006, 93, 685-689. [CrossRef]

44. Man, K.; Lo, C.M.; Liu, C.L.; Zhang, Z.W.; Lee, T.K.; Ng, I.O.; Fan, S.T.; Wong, J. Effects of the intermittent Pringle manoeuvre on hepatic gene expression and ultrastructure in a randomized clinical study. Br. J. Surg. 2003, 90, 183-189. [CrossRef]

45. Man, K.; Fan, S.T.; Ng, I.O.; Lo, C.M.; Liu, C.L.; Wong, J. Prospective evaluation of Pringle maneuver in hepatectomy for liver tumors by a randomized study. Ann. Surg. 1997, 226, 704-711. [CrossRef] [PubMed]

46. Famularo, S.; Giani, A.; Di Sandro, S.; Sandini, M.; Giacomoni, A.; Pinotti, E.; Lauterio, A.; Gianotti, L.; De Carlis, L.; Romano, F. Does the Pringle maneuver affect survival and recurrence following surgical resection for hepatocellular carcinoma? A western series of 441 patients. J. Surg. Oncol. 2018, 117, 198-206. [CrossRef]

47. Jiang, J.H.; Wang, K.X.; Zhu, J.Y.; Yang, P.P.; Guo, Z.; Ma, S.L.; Lü, Y.; Xiang, B.D.; Zhong, J.H.; Li, L.Q. Comparison of hepatectomy with or without hepatic inflow occlusion in patients with hepatocellular carcinoma: A single-center experience. Minerva Med. 2017, 108, 324-333.

48. Hao, S.; Chen, S.; Yang, X.; Wan, C. Adverse impact of intermittent portal clamping on long-term postoperative outcomes in hepatocellular carcinoma. Ann. R. Coll. Surg. Engl. 2017, 99, 22-27. [CrossRef] [PubMed]

49. Hao, S.; Chen, S.; Yang, X.; Wan, C. Impact of intermittent portal clamping on the early recurrence of hepatocellular carcinoma after surgery. Surg. Today 2016, 46, 1290-1295. [CrossRef] [PubMed]

50. Huang, J.; Tang, W.; Hernandez-Alejandro, R.; Bertens, K.A.; Wu, H.; Liao, M.; Li, J.; Zeng, Y. Intermittent hepatic inflow occlusion during partial hepatectomy for hepatocellular carcinoma does not shorten overall survival or increase the likelihood of tumor recurrence. Medicine 2014, 93, e288. [CrossRef]

51. Ishizuka, M.; Kubota, K.; Kita, J.; Shimoda, M.; Kato, M.; Sawada, T. Duration of hepatic vascular inflow clamping and survival after liver resection for hepatocellular carcinoma. Br. J. Surg. 2011, 98, 1284-1290. [CrossRef]

52. Lee, K.F.; Chong, C.C.N.; Cheung, S.Y.S.; Wong, J.; Fung, A.K.Y.; Lok, H.T.; Lai, P.B.S. Impact of intermittent Pringle maneuver on long-term survival after hepatectomy for hepatocellular carcinoma: Result from two combined randomized controlled trials. World J. Surg. 2019, 43, 3101-3109. [CrossRef] [PubMed]

53. Xu, W.; Xu, H.; Yang, H.; Liao, W.; Ge, P.; Ren, J.; Sang, X.; Lu, X.; Zhong, S.; Mao, Y. Continuous Pringle maneuver does not affect outcomes of patients with hepatocellular carcinoma after curative resection. Asia Pac. J. Clin. Oncol. 2017, 13, e321-e330. [CrossRef]

54. Liu, S.; Li, X.; Li, H.; Guo, L.; Zhang, B.; Gong, Z.; Zhang, J.; Ye, Q. Longer duration of the Pringle maneuver is associated with hepatocellular carcinoma recurrence following curative resection. J. Surg. Oncol. 2016, 114, 112-118. [CrossRef]

55. Li, X.; Liu, S.; Li, H.; Guo, L.; Zhang, B.; Lin, Z.; Zhang, J.; Ye, Q. Proper hepatic pedicle clamping during hepatectomy is associated with improved postoperative long-term prognosis in patients with AJCC stage IIIB hepatocellular carcinoma Oncotarget 2016, 7, 24623-24632. [CrossRef] [PubMed]

56. Xia, F.; Lau, W.Y.; Xu, Y.; Wu, L.; Qian, C.; Bie, P. Does hepatic ischemia-reperfusion injury induced by hepatic pedicle clamping affect survival after partial hepatectomy for hepatocellular carcinoma? World J. Surg. 2013, 37, 192-201. [CrossRef] [PubMed]

57. Lin, N.; Li, J.; Ke, Q.; Xin, F.; Zeng, Y.; Wang, L.; Liu, J. Does the intermittent Pringle maneuver affect the recurrence following surgical resection for hepatocellular carcinoma? A systematic review. PLoS ONE 2020, 15, e0229870. [CrossRef]

58. Matsuda, A.; Miyashita, M.; Matsumoto, S.; Matsutani, T.; Sakurazawa, N.; Akagi, I.; Kishi, T.; Yokoi, K.; Uchida, E. Hepatic pedicle clamping does not worsen survival after hepatic resection for colorectal liver metastasis: Results from a systematic review and meta-analysis. Ann. Surg. Oncol. 2013, 20, 3771-3778. [CrossRef]

59. Nakajima, Y.; Shimamura, T.; Kamiyama, T.; Matsushita, M.; Sato, N.; Todo, S. Control of intraoperative bleeding during liver resection: Analysis of a questionnaire sent to 231 Japanese hospitals. Surg. Today 2002, 32, 48-52. [PubMed] 
60. Jones, T.J.; Murphy, A.E.; Tameron, A.; Hussain, L.R.; Grannan, K.; Guend, H.; Dunki-Jacobs, E.M.; Lee, D.Y. Trends and outcomes of synchronous resection of colorectal metastasis in the modern Era-Analysis of targeted hepatic NSQIP database. J. Surg. Res. 2019, 238, 35-40. [CrossRef]

61. van der Bilt, J.D.; Livestro, D.P.; Borren, A.; van Hillegersberg, R.; Borel Rinkes, I.H. European survey on the application of vascular clamping in liver surgery. Dig. Surg. 2007, 24, 423-435. [CrossRef]

62. Rahbari, N.N.; Wente, M.N.; Schemmer, P.; Diener, M.K.; Hoffmann, K.; Motschall, E.; Schmidt, J.; Weitz, J.; Buchler, M.W. Systematic review and meta-analysis of the effect of portal triad clamping on outcome after hepatic resection. Br. J. Surg. 2008, 95, 424-432. [CrossRef] [PubMed]

63. Wells, G.A.; Shea, B.; O'Connell, D.; Peterson, J.; Welch, V.; Losos, M.; Tugwell, P. The Newcastle-Ottawa Scale (NOS) for Assessing the Quality of Nonrandomised Studies in Meta-Analyses. Available online: http://www.ohri.ca/programs/clinical_ epidemiology / oxford.asp (accessed on 18 September 2020).

64. Chaimani, A.; Salanti, G. Visualizing assumptions and results in networkmeta-analysis: The network graphs package. Stata J. 2015, 15, 905-950. [CrossRef]

65. DerSimonian, R.; Laird, N. Meta-Analysis in clinical trials. Control. Clin. Trials 1986, 7, 177-188. [CrossRef]

66. Higgins, J.; Thomas, J.; Chandler, J.; Cumpston, M.; Li, T.; Page, M.; Welch, V. Cochrane Handbook for Systematic Reviews of Interventions Version 6.0 (Updated July 2019); Cochrane: London, UK, 2019; Available online: https: / www.training.cochrane.org/ handbook (accessed on 18 September 2020).

67. Hozo, S.P.; Djulbegovic, B.; Hozo, I. Estimating the mean and variance from the median, range, and the size of a sample. BMC Med. Res. Methodol. 2005, 5, 13. [CrossRef]

68. GetData Graph Digitizer. Available online: http:/ / getdata-graph-digitizer.com/ (accessed on 30 April 2020). 